\title{
A Literature Review of the Effects of Energy on Pollution and Health
}

\author{
Hongshan $\mathrm{Ai}^{1}$, Xiaoqing $\operatorname{Tan}^{2}$ a \\ 1 School of Economics and Trade, Hunan University, China; Hunan Key Laboratory of Energy Internet Supply-demand and Operation, China, 2 School \\ of Economics and Trade, Hunan University, China \\ Keywords: energy, pollution, health \\ https://doi.org/10.46557/001c.28135
}

\section{Energy RESEARCH LETTERS}

Vol. 2, Issue 4, 2021

This paper reviews recent economic studies that estimate the impacts of energy accidents and energy-related policies and regulations on pollution and health. Using difference-in-differences and regression discontinuity designs, most papers show that energy accidents and consumption significantly increased pollution and had adverse health effects. However, the enforcement of clean energy policies and strict regulations have improved air quality and mitigated the negative effects on health. Hence, future research should focus more on the health effects of clean energy in developing countries.

\section{Introduction}

Many people live in places where the average air quality is above the World Health Organization's suggested limits for pollutants. Pollution is currently the most severe environmental problem and public health concern in the world, especially in developing countries. Studies have mostly focused on the causal effect of pollution on health, and numerous economic studies have documented that pollution is severely harmful to human health, in both developed and developing countries.

With rapid industrialization, energy consumption has increased dramatically. As energy raises our quality of life to higher levels, it also puts our health at risk. There is now a growing literature on the impacts of energy accidents and consumption on pollution and health. It finds that pollution is the most relevant channel related to the health impacts of energy. Recent research suggests that the health of pregnant women, children, and infants is at greater risk of being adversely affected by pollution (e.g., Currie \& Neidell, 2005; Janke, 2014). Many studies suggest that infants are sensitive to the pollution caused by oil spills and coal smoke. In addition, studies are increasingly suggesting that clean energy policies and environmental regulations can abate the negative health effects of energy-related pollution.

This paper reviews the recent literature that studies the effects of energy on pollution and health. The core of this causal evaluation addresses the endogeneity problem. Using exogenous energy accidents and policy experiments and regulations as exogenous events to test causality, the literature is mainly based on difference-in-differences and regression discontinuity designs.

On the one hand, given the population explosion and rapid urbanization, energy consumption and the volume of long-distance energy transnational transportation has increased rapidly, and energy accidents, such as the oil spill in the Gulf of Mexico in 2010 and the nuclear leak of Fukushima Daiichi in Japan, are occurring frequently. Therefore, research has documented the impacts of energy accidents on pollution and human health. In response to public concerns over the increasing pollution threat from energy consumption and accidents, governments can put forward various policies and regulations to mitigate the negative health effects. Therefore, this paper aims to review the recent literature and determine how energy affects pollution and health.

\section{Impacts of energy accidents and consumption on pollution and health}

Table 1 lists and categorizes selected economic studies on the impacts of energy accidents and consumption on pollution and health. Environmental disasters caused by energy accidents and general energy consumption can cause pollution, and the problem of human exposure to pollution is attracting greater attention. The literature on the health effects of oil pollution has also been growing rapidly. Many recent papers find oil to have a negative impact on pollution and health. Beland and Oloomi (2019) and Marcus (2021) quantify the health impact of petroleum pollution on infant health in the United States by using the 2010 oil spill in the Gulf of Mexico and the leakage of underground storage tanks as exogenous events. Exploiting a difference-in-differences design, Beland and Oloomi (2019) find that the oil spill of 2010 raised concentrations of $\mathrm{PM}_{2.5}$, $\mathrm{NO}_{2}, \mathrm{SO}_{2}$, and $\mathrm{CO}$ in the affected coastal counties and increased the incidence of low-birthweight and prematurely born infants. Marcus (2021) finds that exposure to a leak- 
ing underground storage tank during gestation increases the probability of both low birthweight and preterm birth by $7-8 \%$. In addition, all the studies mentioned above find that prenatal exposure to pollution had a heterogeneous impact on mothers with different individual characteristics (age, race, marital status, etc.). The infants of black, Hispanic, less educated, unmarried, and younger mothers suffer from more pronounced adverse health outcomes (Beland \& Oloomi, 2019). Marcus (2021) also finds that the adoption of preventative technologies mitigated the entire effect of storage tank leak exposure on birthweight, and information increased avoidance and moving among highly educated mothers.

In addition to environmental disasters such as oil spills and leakage, general energy consumption has an impact on air quality and health. In particular, the decline in air quality caused by coal fires and straw burning leads directly to an increase in mortality. Beach and Hanlon (2018) provide the first estimate of the mortality effects of British industrial coal use in 1851-1860. The results indicate that local industrial pollution had a powerful impact on mortality. Raising local industrial coal use by one standard deviation above the mean increased infant mortality by roughly $6-8 \%$ and mortality among children under five by $8-15 \%$.

Farmers often burn straw after a harvest, which is the main cause of seasonal air pollution in developing countries. Based on agricultural straw burning satellite data, $\mathrm{He}$ et al. (2020) use non-local straw burning as an instrumental variable for air pollution to estimate the impact of straw burning on air pollution and health. The results show that straw burning increased particulate matter pollution and caused people to die from cardiorespiratory diseases. Middle-aged individuals and the elderly in rural areas are more sensitive to such pollution. Furthermore, using a difference-in differences approach, the authors find that China's recent straw recycling policy has effectively improved the country's air quality.

\section{Impacts of energy policies and regulations on pollution and health}

Due to the negative impacts of energy accidents and consumption on pollution and health, more and more energyrelated policies and regulations are established by governments to alleviate the negative effects of air quality on health. These policies and regulations provide exogenous shocks for identifying a causal relationship. A growing re- search literature has begun to focus on how energy policies and energy-related environmental regulations can affect pollution and health. As Table 2 shows, many papers examine the causal relationship between energy policies or regulations and pollution (health), using a difference-in-differences design and regression discontinuity analyses. Imelda (2020) investigates the health impacts of household access to cleaner fuel through a nationwide fuel-switching program. The results suggest that the program led to a significant decline in infant mortality and that fetal exposure to indoor air pollutants is an important channel. Fan et al. (2020) focus on China's coal-fired winter heating systems, the country with the largest and most expensive energy welfare policies in the developing world. The authors estimate the contemporaneous impact of winter heating on air pollution and health by using regression discontinuity designs and find that such winter heating systems increased the weekly Air Quality Index by $36 \%$ and mortality by $14 \%$. Fan et al. (2020) and Imelda (2020) both suggest that the health impact of air pollution can be mitigated by improving socioeconomic conditions.

Based on the fact that coal and gasoline fuels emit a huge number of harmful pollutants, many targeted environmental regulations have been enforced to reduce pollution and improve health welfare. Yang and Chou (2018) find that the shutdown of power plants located upwind of New Jersey reduced the likelihood of having a low-birthweight or preterm infant by $15 \%$ and $28 \%$, respectively. Strict command-andcontrol energy regulation policies have obvious effects. Because of limited financial resources and staff, developing countries are constrained in terms of their regulatory capacity to enforce regulations. Evidence from better developed economies might not be readily generalizable to the developing world. Li et al. (2020) and Zhu and Wang (2021) examine the causal effects of China's prefecture-level fuel standards and fuel content regulation on air pollution at ports. Their papers bridge the gap by documenting novel empirical evidence and measure the benefits of fuel standards in the world's largest developing country. Li et al. (2020) find that the enforcement of high-quality gasoline standards significantly reduced average pollution by $12.9 \%$, and improved air quality. Their conclusion demonstrates the importance of fuel quality. Zhu and Wang (2021) show that fuel content regulation at ports immediately reduced major types of pollutants by more than $15 \%$. 
Table 1. A selection of published empirical papers on the pollution and health effects of energy accidents and consumption.

\begin{tabular}{|c|c|c|c|c|c|c|c|}
\hline Reference & Area & Types & Background & $\begin{array}{l}\text { Empirical } \\
\text { Strategy }\end{array}$ & Outcomes & Heterogeneity & Mechanism \\
\hline $\begin{array}{l}\text { Beach and Hanlon } \\
\text { (2018), EJ }\end{array}$ & $\begin{array}{l}\text { Alabama, Florida, Louisiana, } \\
\text { and Mississippi, U.S. }\end{array}$ & Oil pollution & $\begin{array}{l}\text { The } 2010 \text { oil spill in } \\
\text { the Gulf of Mexico }\end{array}$ & DID & $\begin{array}{l}\text { Air quality, } \\
\text { infant health }\end{array}$ & $\begin{array}{l}\text { Race, education, } \\
\text { marital status, age }\end{array}$ & \\
\hline $\begin{array}{l}\text { Beland and } \\
\text { Oloomi (2019), } \\
\text { JEEM }\end{array}$ & British & Coal-based pollution & & OLS & $\begin{array}{l}\text { Infant } \\
\text { Mortality, } \\
\text { mortality }\end{array}$ & Age & \\
\hline $\begin{array}{l}\text { He, Liu and Zhou } \\
\text { (2020), JDE }\end{array}$ & Chinese counties & $\begin{array}{l}\text { Straw burning, China's recent } \\
\text { straw recycling policy }\end{array}$ & & IV, DID & $\begin{array}{l}\text { Air pollution, } \\
\text { death }\end{array}$ & $\begin{array}{l}\text { Location, gender, } \\
\text { age }\end{array}$ & \\
\hline $\begin{array}{l}\text { Marcus (2021), } \\
\text { AEJ: Applied }\end{array}$ & $\begin{array}{l}\text { Pennsylvania, Florida and } \\
\text { New Jersey, U.S. }\end{array}$ & Petroleum pollution & $\begin{array}{l}\text { Leaking underground } \\
\text { storage tank }\end{array}$ & OLS, DID & Infant health & $\begin{array}{l}\text { Race, ethnicity, } \\
\text { education }\end{array}$ & $\begin{array}{l}\text { Groundwater } \\
\text { pollution }\end{array}$ \\
\hline
\end{tabular}

Table 2. A selection of published empirical papers on the pollution and health effects of energy policies and regulations.

\begin{tabular}{|c|c|c|c|c|c|c|c|}
\hline Reference & Area & Types & Background & $\begin{array}{l}\text { Empirical } \\
\text { Strategy }\end{array}$ & Outcomes & Heterogeneity & Mechanism \\
\hline $\begin{array}{l}\text { Yang and } \\
\text { Chou } \\
\text { (2018), } \\
\text { JEEM }\end{array}$ & $\begin{array}{l}\text { New Jersey, } \\
\text { U.S. }\end{array}$ & Coal-fired & The shutdown of a coal-fired power plant & DID & $\begin{array}{l}\text { Fetal } \\
\text { health }\end{array}$ & $\begin{array}{l}\text { Gender, } \\
\text { education }\end{array}$ & \\
\hline $\begin{array}{l}\text { Fan, He and } \\
\text { Zhou (2020), } \\
\text { JHE }\end{array}$ & $\begin{array}{c}114 \\
\text { northern } \\
\text { Chinese } \\
\text { cities, }\end{array}$ & $\begin{array}{l}\text { Coal-fired } \\
\text { heating }\end{array}$ & China's winter heating policy & RD & $\begin{array}{l}\text { Air } \\
\text { pollution, } \\
\text { mortality }\end{array}$ & $\begin{array}{l}\text { Social-economic } \\
\text { conditions, } \\
\text { gender, age }\end{array}$ & \\
\hline $\begin{array}{l}\text { Li, Lu and } \\
\text { Wang } \\
\text { (2020), JDE }\end{array}$ & China & $\begin{array}{c}\text { Fuel } \\
\text { standards }\end{array}$ & $\begin{array}{l}\text { Changes in standards for fuel sold in Chinese } \\
\text { cities }\end{array}$ & DID, RD & $\begin{array}{c}\text { Air } \\
\text { pollution }\end{array}$ & Temporal, spatial & \\
\hline $\begin{array}{l}\text { Imelda } \\
\text { (2020), JDE }\end{array}$ & Indonesia & $\begin{array}{l}\text { Cleaner } \\
\text { energy } \\
\text { access }\end{array}$ & Household cooking fuel conversion program & DID & $\begin{array}{l}\text { Infant } \\
\text { health }\end{array}$ & $\begin{array}{l}\text { Gender, urban- } \\
\text { rural } \\
\text { classification, }\end{array}$ & $\begin{array}{l}\text { Indoor air pollution, fuel expenditure, } \\
\text { fuel-stacking behavior, behavioral } \\
\text { changes }\end{array}$ \\
\hline $\begin{array}{l}\text { Zhu and } \\
\text { Wang } \\
\text { (2021), } \\
\text { JEEM }\end{array}$ & China & $\begin{array}{l}\text { Fuel } \\
\text { content } \\
\text { regulation }\end{array}$ & $\begin{array}{l}\text { The initial enforcement of fuel-content } \\
\text { regulation at four ports of the Yangtze River } \\
\text { Delta }\end{array}$ & DID & $\begin{array}{l}\text { Regional } \\
\text { pollution }\end{array}$ & & \\
\hline
\end{tabular}




\section{Conclusion}

To sum up, the economic studies on the impact of energy on pollution and health are becoming richer. Methodologically, these studies typically use difference-in-differences and regression discontinuity designs to evaluate the causal effects of energy accidents, policies, and regulations on pollution and health. Several studies support negative effects on air quality and infant health, and all of these find that energy policies and regulations can reduce regional pollution and improve health welfare, especially in less developed countries and areas. Furthermore. resources and information should target pregnant women to help mitigate poor infant health. The findings can have important implications for countries besides China, including developing ones.

The papers covered in this review contribute to cost-benefit analysis by quantifying the pollution and health effects from energy accidents, policies, and regulations. The largest energy transition projects are being attempted in many developing countries, and further research is needed to fully understand the long-term health effects of clean energy in developing countries. 


\section{REFERENCES}

Beach, B., \& Hanlon, W. W. (2018). Coal smoke and mortality in an early industrial economy [J]. The Economic Journal, 128(615), 2652-2675. https://doi.or $\mathrm{g} / 10.1111 /$ ecoj.12522

Beland, L.-P., \& Oloomi, S. (2019). Environmental disaster, pollution and infant health: Evidence from the Deepwater Horizon oil spill [J]. Journal of Environmental Economics and Management, 98, 102265. https://doi.org/10.1016/i.jeem.2019.102265

Currie, J., \& Neidell, M. (2005). Air pollution and infant health: What can we learn from California's recent experience [J]. The Quarterly Journal of Economics, 120(3), 1003-1030.

Fan, M. Y., He, G. J., \& Zhou, M. G. (2020). The winter choke: Coal-Fired heating, air pollution, and mortality in China [J]. Journal of Health Economics, 71, 102316. https://doi.org/10.1016/j.jhealeco.2020.10231 $\underline{6}$

He, G. J., Liu, T., \& Zhou, M. G. (2020). Straw burning, PM2.5, and death: Evidence from China [J]. Journal of Development Economics, 145, 102468. https://doi.org/1 $\underline{0.1016 / j . j d e v e c 0.2020 .102468}$

Imelda. (2020). Cooking that kills: Cleaner energy access, indoor air pollution, and health [J]. Journal of Development Economics, 147, 102548. https://doi.org/1 $\underline{0.1016 / j . j d e v e c o .2020 .102548}$
Janke, K. (2014). Air pollution, avoidance behaviour and children's respiratory health: Evidence from England [J]. Journal of Health Economics, 38, 23-42. https://do i.org/10.1016/i.jhealeco.2014.07.002

Li, P., Lu, Y., \& Wang, J. (2020). The effects of fuel standards on air pollution: Evidence from China [J]. Journal of Development Economics, 146, 102488. http s://doi.org/10.1016/j.jdeveco.2020.102488

Marcus, M. (2021). Going beneath the surface: Petroleum pollution, regulation, and health [J]. American Economic Journal: Applied Economics, 13(1), 1-37.

Yang, M. Z., \& Chou, S.-Y. (2018). The impact of environmental regulation on fetal health: Evidence from the shutdown of a coal-fired power plant located upwind of New Jersey [J]. Journal of Environmental Economics and Management, 90, 269-293. https://do i.org/10.1016/j.jeem.2018.05.005

Zhu, J. M., \& Wang, J. L. (2021). The effects of fuel content regulation at ports on regional pollution and shipping industry [J]. Journal of Environmental Economics and Management, 106, 102424. https://do i.org/10.1016/i.jeem.2021.102424 